\title{
Characterization and Development of Yoghurt from Concentrated Whey
}

\author{
Abdul Ahid Rashid", Nuzhat Huma ${ }^{2}$, Salman Saeed ${ }^{1}$, Khurram Shahzad ${ }^{1}$, Ishtiaque Ahmad ${ }^{3}$, , \\ Ijaz Ahmad ${ }^{1}$, Shaista Nawaz ${ }^{1}$, Muhammad Imran ${ }^{4}$ \\ ${ }^{1}$ Food \& Biotechnology Research Centre, Pakistan Council of Scientific Industrial Research Centre, Lahore, Pakistan \\ ${ }^{2}$ National Institute of Food Science \& Technology, University of Agriculture, Faisalabad, Pakistan \\ ${ }^{3}$ Department of Dairy Technology, University of Veterinary \& Animal Sciences, Lahore, Pakistan \\ ${ }^{4}$ Institute of Biochemistry \& Biotechnology, University of Veterinary \& Animal Sciences, Lahore, Pakistan
}

\section{Email address:}

ch.abdulahid@gmail.com (A. A. Rashid),drnuzhathuma@gmail.com (N. Huma), salmaansaeed@gmail.com (S. Saeed), khurrampcsir74@yahoo.com (K. Shahzad), ishtiaque@uvas.edu.pk (I. Ahmad),ijazft@yahoo.com (I. Ahmad), snpcsir1@hotmail.com (S. Nawaz), imran.khan@uvas.edu.pk (M. Imran)

${ }^{*}$ Corresponding author

\section{To cite this article:}

Abdul Ahid Rashid, Nuzhat Huma, Salman Saeed, Khurram Shahzad, Ishtiaque Ahmad, Ijaz Ahmad, Shaista Nawaz, Muhammad Imran. Characterization and Development of Yoghurt from Concentrated Whey. International Journal of Food Engineering and Technology. Vol. 3, No. 1, 2019, pp. 1-7. doi: 10.11648/j.ijfet.20190301.11

Received: November 12, 2018; Accepted: January 24, 2019; Published: February 15, 2019

\begin{abstract}
Yoghurt is very rich in proteins, mineral, vitamins and other nutrients. Concentrated whey (CW) of buffalo cheddar cheese was used at concentrations of 5,10,15,20,25 and 30\% in buffalo milk to increase the solids with reduction of fat in set yoghurt. These yoghurt samples were compared with control sample for physicochemical characteristics like acidity, protein, lactose, total solids, $\mathrm{pH}$, syneresis, water holding capacity (WHC) and viscosity for 21 days at intervals of 7 days. The high concentration of whey significantly $(\mathrm{p}<0.05)$ increased the protein, lactose, solid contents, syneresis, viscosity while the WHC was decreased. However, $\mathrm{pH}$ decreased in the yoghurt with 5, 10, 15 and 20\% CW, but vice versa in the yoghurt with $25 \% \mathrm{CW}$ due to the high concentration of lactose in $\mathrm{CW}$. Fat, protein, lactose contents, $\mathrm{pH}$, WHC and viscosity decreased while acidity, non-protein nitrogen and syneresis increased significantly during storage.
\end{abstract}

Keywords: Concentrated Whey, Buffalo Milk, Yoghurt, Syneresis, Water Holding Capacity

\section{Introduction}

Essential nutrients required by the human body can be fulfilled from buffalo milk, which is one of the rich sources of major and minor food supplements [1]. Fermented milk products are an integral part of traditional foods world over. Milk products prepared by the lactic acid fermentation of milk containing a mixture of Streptococcus salivarius subsp. thermophilus and Lactobacillus delbrueckii subsp. bulgaricus is called yoghurt $[32,36]$. After culturing the milk, a firm gel is formed by casein coagulates which are composed of casein micelle and whey linked by hydrogen bonds. Yoghurt structure is the result of cross-linking and interaction of the $\mathrm{K}$-casein with denatured whey proteins present on the outer layer of casein micelles via disulfide bonding. The yoghurt
$\mathrm{pH}$ decreases up to 4.6 from 6.6 during fermentation, it is the isoelectric point of casein protein. Yoghurt texture quality is mostly affected by heat treatment, starter culture and shearing of yoghurt after fermentation [33, 37]. Rheological and physical characteristics of yoghurt exposed the value of product and consumer acceptance. These characteristics of yoghurt are affected by fortification during processing and processing conditions [10]. The yoghurt quality is maintained with consistency, optimum stability, an acceptable firmness and lack of syneresis. Therefore, the standardization level of total milk solids is vital for yoghurt manufacturing for both its stability and consistency. Textural characteristics of yoghurt depend on the increase in protein content of milk before fermentation process [33]. Conventionally, the total milk solids are increased for yoghurt production by (i) 
addition of protein powders (skimmed milk) (ii) water removal by membrane filtration; or (iii) under vacuum water evaporation [37]. Researchers supported the addition of whey concentrates into yoghurt owing to decrease in the free water immobilization and syneresis [19]. The addition of whey increases the total milk protein contents, improve the viscosity and texture of the yoghurt [26]. Whey protein concentrates (WPC) offers a cost-effective substitute to skim milk powder (SMP), whey proteins also contribute to the functional and nutritional characteristics of yoghurt. The quality of yoghurt prepared with WPC is observed by the whey protein modifications while the final quality also depends on their interaction in the yoghurt mix with casein [21]. Use of various levels of concentrated whey can affect the yoghurt quality characteristics and acceptability. Increase in protein and total solids (TS) improve the consistency and texture of yoghurt $[3,36]$. Whey protein of yoghurt also enhance the total protein content and its viscosity [26]. High level of denaturation of whey protein $(>50 \%)$ caused by high-heat treatment, it is associated with a marked increase in complex viscosity. Sufficient denaturation of whey protein $\geq 80 \%$ occurs when yoghurt blend was pasteurized at $95^{\circ} \mathrm{C}$ for $5 \mathrm{~min}$ or $85^{\circ} \mathrm{C}$ for $30 \mathrm{~min}$ [21]. Denatured whey proteins form complexes with casein micelles in yoghurt mix [6]. Therefore, if the milk is heated $\geq 80^{\circ} \mathrm{C}$, whey proteins unfold the reactive thiol groups become available (cysteine) [20]. Yoghurt proteins are hydrolyzed increasing their availability. Whey proteins (mainly $\alpha$-lactalbumin and $\beta$-lactoglobulin) remain in yoghurt in comparison with cheeses. Nutritional value of yoghurt increased by the contribution of these factors [8]. So, keeping in mind the functional and nutritional value of the concentrated whey, the current study was commenced the production of yoghurt with concentrated whey $(\mathrm{CW})$ and its effect on the physicochemical and qualitative characteristics of yoghurt was examined during storage at $4 \pm 2^{\circ} \mathrm{C}$ for 21 days.

\section{Methods}

\subsection{Procurement}

Buffalo milk was procured from the dairy farm of the university of agriculture, Faisalabad, Pakistan. Whey was procured from the cheese industry (nurpur dairies Bhalwal, Pakistan) and commercial starter culture (Lactobacillus bulgaricus and Streptococcus thermophilus) was procured from Orchard Valley Dairy Supplies, UK.

\subsection{Preparation of Concentrated Whey}

Whey was concentrated by under vacuum concentrator in pilot plant production unit of Food and Biotechnology Research Centre, PCSIR Laboratories Complex, Lahore. The control process of whey concentration was optimized regard several variables such as temperature and vacuum pressure. Whey was concentrated at $60^{\circ} \mathrm{C}$, with $0.05 \mathrm{mpa}$ vacuum pressure.

\subsection{Development of Set Yoghurt with Concentrated Whey}

Set type yoghurt was prepared by adding concentrated whey into milk to increase the solids not fat (SNF) at various levels with modified process [33]. Raw buffalo milk was standardized at $3.48 \%$ fat and concentrated whey was added at 5, 10, 15, 20, 25 and 30\% levels in milk. Blend (Milk and concentrated whey) of each sample and control sample (without concentrated whey) was maintained at $250 \mathrm{~mL}$ volume. Then, each sample was experimentally pasteurized at $90^{\circ} \mathrm{C}$ in a water bath without agitation for 30 minutes and then cooled to $42^{\circ} \mathrm{C}$. It was inoculated with $0.2 \mathrm{~g} / \mathrm{L}$ starter culture and incubated at $42^{\circ} \mathrm{C}$ for 5 hours until a pH of 4.50 attained. Each yoghurt sample was cooled rapidly to $4^{\circ} \mathrm{C}$ to stop fermentation and stored at 4 to $6^{\circ} \mathrm{C}$.

\subsection{Physicochemical Analysis}

Acidity, $\mathrm{pH}$, total protein, non-protein nitrogen (NPN), fat, lactose, ash and total solids analysis of Buffalo milk, concentrated whey and yoghurt were performed. $\mathrm{pH}$ values were determined by the digital $\mathrm{pH}$ meter [25]. Acidity was measured by titration method No. 947.05 [7]. Fat was analyzed according to Gerber method by butyrometer (Marshall, 1993). Protein was determined by the Kjeldahl apparatus by adopting the method No. 991.20 [7] and NPN contents were determined by the method given in IDF standard 20-4 (2001). Lactose was analyzed by the gravimetric method No. 930.28 [7]. Ash content was evaluated by dry oven method No. 945.46 [7]. Total solids were determined by dry oven method No. 925.23 [7]. Each experiment was conducted in duplicate while analyses of all parameters were carried out in triplicates.

\subsubsection{Syneresis}

The syneresis index in yoghurt was analyzed according to the technique of centrifugation [5]. The yoghurt sample was agitated with a glass rod twenty times anticlockwise and clockwise. Thirty grams yoghurt sample was poured into 50 $\mathrm{mL}$ conical tube and kept for 2 hours at $4^{\circ} \mathrm{C}$. Whey was separated by centrifugation for $15 \mathrm{~min}$ at $3000 \mathrm{rpm}$ at $10^{\circ} \mathrm{C}$. The weight of centrifuged whey was calculated. The syneresis is the weight percentage of the whey isolated from the yoghurt gel over the initial weight of the gel.

\subsubsection{Water Holding Capacity (WHC)}

The WHC of yoghurt was measured by a method of centrifugation [31]. Five grams of yoghurt sample was centrifuged at $4500 \mathrm{rpm}$ at $10^{\circ} \mathrm{C}$ for $30 \mathrm{~min}$, then supernatant was drained, pellet was sedimented and weighed, WHC was estimated according to following Equation. (1):

$$
\mathrm{WHC}=\left[1-\frac{W t}{W i}\right] \times 100
$$

Where $W i$ is initial weight $(\mathrm{g})$ of the yoghurt and $W t$ is weight $(\mathrm{g})$ of the pellet.

\subsubsection{Viscosity}

The viscosity of yoghurt was analyzed using Brookfield 
DV-E Viscometer at $25^{\circ} \mathrm{C}$ with spindle No. 3 for $5 \mathrm{~min}$ at 20 rpm [11].

\subsubsection{Sensory Evaluation}

The appearance \& color, flavor, body \& texture and taste of yoghurt were assessed using the 100-point scorecard [24]. Appearance and color were given maximum 15, flavor 45, body and texture 30 and taste 10 points out of 100 points.

\subsection{Statistical Analysis}

Data of all parameters were evaluated statistically with analysis of variance (ANOVA) Technique, two-factor factorial under completely randomized designs (CRD). Mean values were compared at significance level of 0.05 using
Least Significance Difference (LSD) test [34].

\section{Results}

\subsection{Chemical Analysis of Milk and Concentrated Whey}

Fresh buffalo milk and concentrated whey were analyzed before the preparation of yoghurt (Table 1). The results revealed that buffalo milk showed, $3.75 \%, 3.48 \%$ and $4.71 \%$ of protein, fat and lactose respectively, while the mean values of these ingredients in concentrated whey were $5.64 \%$, $2.57 \%$ and $35.31 \%$, respectively.

Table 1. Chemical analysis of concentrated whey and buffalo milk.

\begin{tabular}{lll}
\hline Parameters & Concentrated whey & Buffalo milk \\
\hline $\mathrm{pH}$ & $4.35 \pm 0.04$ & $6.76 \pm 0.06$ \\
Acidity (\%) & $1.69 \pm 0.03$ & $0.12 \pm 0.01$ \\
Moisture (\%) & $51.38 \pm 0.20$ & $87.15 \pm 0.33$ \\
Ash (\%) & $3.41 \pm 0.04$ & $0.80 \pm 0.02$ \\
Fat (\%) & $2.57 \pm 0.10$ & $3.48 \pm 0.15$ \\
Protein (\%) & $5.64 \pm 0.14$ & $3.75 \pm 0.06$ \\
NPN (\%) & $1.17 \pm 0.051$ & $0.13 \pm 0.01$ \\
Lactose (\%) & $35.31 \pm 0.19$ & $4.71 \pm 0.04$ \\
Total solids (\%) & $48.62 \pm 0.25$ & $12.85 \pm 0.17$ \\
\hline
\end{tabular}

Value are expressed as mean \pm S.E

It is evident from previous studies that the whey concentrate had acidity, milk fat, crude protein, NPN, lactose, ash and total solid contents were $2.63 \%, 2.33 \%, 4.53 \%$, $1.13 \%, 36.81 \%, 4.03 \%$, and $48.68 \%$, respectively [14]. Previous study shows that mean values of concentrated sweet whey found that acidity $2.07 \%$, lactose $36.40 \%$, crude protein $8.25 \%$, dry matter $64.35 \%$ and salts $2.59 \%$ compared with the concentrated acid whey which had $4.95 \%, 30.13 \%$, $4.06 \%, 68.98 \%$ and $14.56 \%$, respectively [4]. It was observed that the whey protein used for Ricotta cheese production had lactose $4.1 \%$, protein $7.41 \%$, ash $2.3 \%$ and total solid contents $13.95 \%$ of concentrated whey [13].

\subsection{Chemical Analysis of Yoghurt}

Results of all physicochemical parameters presented significant effects $(p<0.05)$ except fat $(\%)$ which revealed non-significant effect in yoghurt samples. Significant $(p<0.05)$ effects were observed in lactose, $\mathrm{pH}$, acidity, protein and non-protein nitrogen, while ash and total solids had nonsignificant effects $(p>0.05)$ during 21 days of storage at $4 \pm 2{ }^{\circ} \mathrm{C}$ (Table 2).

Table 2. Effect of treatments and storage on proximate composition of yoghurt.

\begin{tabular}{|c|c|c|c|c|c|}
\hline \multirow{2}{*}{$\begin{array}{l}\text { Composition } \\
\text { component }\end{array}$} & \multirow{2}{*}{ Treatments } & \multicolumn{4}{|l|}{ Storage period } \\
\hline & & 0 day & 7 days & 14 days & 21 days \\
\hline \multirow{6}{*}{$\mathrm{pH}$} & Y0 & $4.58 \pm 0.013^{\mathrm{a}}$ & $4.48 \pm 0.021^{\mathrm{bc}}$ & $4.23 \pm 0.021^{\mathrm{h}}$ & $3.86 \pm 0.019^{k}$ \\
\hline & Y1 & $4.52 \pm 0.020^{b}$ & $4.36 \pm 0.020^{\mathrm{ef}}$ & $4.11 \pm 0.015^{\mathrm{j}}$ & $3.83 \pm 0.027^{1}$ \\
\hline & Y2 & $4.41 \pm 0.023^{\mathrm{c}}$ & $4.26 \pm 0.015^{\mathrm{gh}}$ & $4.08 \pm 0.018^{\mathrm{j}}$ & $3.70 \pm 0.023^{\mathrm{m}}$ \\
\hline & Y3 & $4.31 \pm 0.018^{\mathrm{d}}$ & $4.18 \pm 0.020^{\mathrm{i}}$ & $3.91 \pm 0.026^{\mathrm{k}}$ & $3.66 \pm 0.021^{\circ}$ \\
\hline & Y4 & $4.27 \pm 0.022^{\mathrm{de}}$ & $4.12 \pm 0.018^{j}$ & $3.95 \pm 0.009^{\mathrm{m}}$ & $3.57 \pm 0.026^{\mathrm{p}}$ \\
\hline & Y5 & $4.20 \pm 0.026^{\mathrm{fg}}$ & $3.97 \pm 0.017^{\mathrm{k}}$ & $3.83 \pm 0.028^{\mathrm{m}}$ & $3.51 \pm 0.015^{\mathrm{q}}$ \\
\hline \multirow{7}{*}{ Acidity (\%) } & Y0 & $0.68 \pm 0.025^{\mathrm{r}}$ & $0.92 \pm 0.025^{\mathrm{mn}}$ & $1.21 \pm 0.032^{\mathrm{efg}}$ & $1.17 \pm 0.034^{\mathrm{gh}}$ \\
\hline & Y1 & $0.74 \pm 0.020^{\mathrm{qr}}$ & $0.94 \pm 0.021^{\mathrm{lmn}}$ & $1.16 \pm 0.025^{\mathrm{ghi}}$ & $1.19 \pm 0.024^{\mathrm{fgh}}$ \\
\hline & Y2 & $0.80 \pm 0.026^{\mathrm{pq}}$ & $0.98 \pm 0.023^{\mathrm{lm}}$ & $1.25 \pm 0.030^{\text {cdef }}$ & $1.23 \pm 0.026^{\mathrm{defg}}$ \\
\hline & Y3 & $0.85 \pm 0.021^{\mathrm{op}}$ & $1.05 \pm 0.019^{\mathrm{jk}}$ & $1.29 \pm 0.018^{\mathrm{bcd}}$ & $1.31 \pm 0.029^{\mathrm{bc}}$ \\
\hline & Y4 & $0.91 \pm 0.028^{\text {no }}$ & $1.10 \pm 0.012^{\mathrm{ij}}$ & $1.33 \pm 0.015^{\mathrm{ab}}$ & $1.27 \pm 0.021^{\mathrm{bcde}}$ \\
\hline & Y5 & $0.95 \pm 0.018^{\mathrm{lmn}}$ & $1.16 \pm 0.015^{\mathrm{ghi}}$ & $1.38 \pm 0.021^{\mathrm{a}}$ & $1.32 \pm 0.027^{\mathrm{ab}}$ \\
\hline & Y6 & $1.01 \pm 0.027^{\mathrm{kl}}$ & $1.14 \pm 0.024^{\mathrm{hi}}$ & $1.30 \pm 0.028^{\mathrm{bc}}$ & $1.33 \pm 0.031^{\mathrm{ab}}$ \\
\hline \multirow{2}{*}{ Protein $(\%)$} & Y2 & $3.93 \pm 0.021^{\mathrm{jkl}}$ & $3.93 \pm 0.019^{j \mathrm{kl}}$ & $3.89 \pm 0.032^{\mathrm{klm}}$ & $3.86 \pm 0.029^{\mathrm{lmn}}$ \\
\hline & Y3 & $4.03 \pm 0.025^{\mathrm{a}}$ & $4.01 \pm 0.023^{\mathrm{ghi}}$ & $3.98 \pm 0.015^{\mathrm{hij}}$ & $3.96 \pm 0.018^{\mathrm{ijk}}$ \\
\hline
\end{tabular}




\begin{tabular}{|c|c|c|c|c|c|}
\hline \multirow{2}{*}{$\begin{array}{l}\text { Composition } \\
\text { component }\end{array}$} & \multirow{2}{*}{ Treatments } & \multicolumn{4}{|l|}{ Storage period } \\
\hline & & 0 day & 7 days & 14 days & 21 days \\
\hline & Y4 & $4.13 \pm 0.018^{\mathrm{def}}$ & $4.12 \pm 0.024^{\mathrm{def}}$ & $4.10 \pm 0.028^{\text {ef }}$ & $4.08 \pm 0.022 \mathrm{fg}$ \\
\hline & Y5 & $4.22 \pm 0.023^{\mathrm{bc}}$ & $4.21 \pm 0.022^{\mathrm{bc}}$ & $4.18 \pm 0.025^{\mathrm{cd}}$ & $4.17 \pm 0.027^{\text {cd }}$ \\
\hline & Y6 & $4.31 \pm 0.020^{\mathrm{a}}$ & $4.30 \pm 0.031^{\mathrm{a}}$ & $4.28 \pm 0.017^{\mathrm{ab}}$ & $4.27 \pm 0.010^{\mathrm{ab}}$ \\
\hline & Y0 & $0.14 \pm 0.012^{\mathrm{s}}$ & $0.16 \pm 0.015^{\mathrm{rs}}$ & $0.19 \pm 0.013^{\mathrm{qr}}$ & $0.22 \pm 0.016^{\mathrm{opq}}$ \\
\hline & Y1 & $0.18 \pm 0.011^{\mathrm{qr}}$ & $0.21 \pm 0.013^{\mathrm{pq}}$ & $0.24 \pm 0.016^{\mathrm{mnop}}$ & $0.26 \pm 0.018^{\mathrm{klmn}}$ \\
\hline & Y2 & $0.23 \pm 0.013^{\text {nop }}$ & $0.25 \pm 0.005^{\mathrm{lmno}}$ & $0.27 \pm 0.011^{\mathrm{klm}}$ & $0.30 \pm 0.018^{\mathrm{jk}}$ \\
\hline & Y3 & $0.29 \pm 0.013^{\mathrm{jkl}}$ & $0.31 \pm 0.015^{\mathrm{ij}}$ & $0.35 \pm 0.017^{\text {ghi }}$ & $0.38 \pm 0.016^{\mathrm{efgh}}$ \\
\hline \multirow{3}{*}{ NPN (\%) } & Y4 & $0.34 \pm 0.012^{\mathrm{hi}}$ & $0.36 \pm 0.014^{\text {fgh }}$ & $0.38 \pm 0.016^{\mathrm{efg}}$ & $0.40 \pm 0.017^{\mathrm{de}}$ \\
\hline & Y5 & $0.39 \pm 0.015^{\mathrm{ef}}$ & $0.42 \pm 0.013^{\mathrm{de}}$ & $0.44 \pm 0.016^{\mathrm{cd}}$ & $0.47 \pm 0.014^{\mathrm{bc}}$ \\
\hline & Y6 & $0.47 \pm 0.014^{\mathrm{bc}}$ & $0.46 \pm 0.017^{\mathrm{bc}}$ & $0.49 \pm 0.013^{\mathrm{ab}}$ & $0.52 \pm 0.015^{\mathrm{a}}$ \\
\hline \multirow{2}{*}{ Lactose (\%) } & Y0 & $4.45 \pm 0.209^{1}$ & $4.14 \pm 0.241^{1 \mathrm{~m}}$ & $3.78 \pm 0.198^{\mathrm{m}}$ & $3.74 \pm 0.153^{\mathrm{m}}$ \\
\hline & Y1 & $6.19 \pm 0.167^{j}$ & $5.65 \pm 0.206^{\mathrm{k}}$ & $5.37 \pm 0.188^{\mathrm{k}}$ & $5.30 \pm 0.206^{\mathrm{k}}$ \\
\hline $\mathrm{Y} 2$ & 7.64 & & $7.13 \pm 0.188^{\mathrm{i}}$ & $6.82 \pm 0.220^{\mathrm{i}}$ & $6.81 \pm 0.199^{\mathrm{i}}$ \\
\hline Y3 & 9.17 & & $8.68 \pm 0.241^{\mathrm{fg}}$ & $8.38 \pm 0.205^{\mathrm{g}}$ & $8.36 \pm 0.231^{\mathrm{g}}$ \\
\hline Y4 & 10.6 & & $10.20 \pm 0.199^{\mathrm{de}}$ & $10.06 \pm 0.217^{\mathrm{e}}$ & $10.09 \pm 0.222^{\mathrm{e}}$ \\
\hline Y5 & 12.1 & & $11.71 \pm 0.238^{\mathrm{bc}}$ & $11.48 \pm 0.238^{c}$ & $11.56 \pm 0.202^{\mathrm{c}}$ \\
\hline Y6 & 13.5 & & $13.40 \pm 0.179^{\mathrm{a}}$ & $13.26 \pm 0.191^{\mathrm{a}}$ & $13.22 \pm 0.171^{\mathrm{a}}$ \\
\hline
\end{tabular}

The $\mathrm{pH}$ and acidity of Y0 (control) were 4.29 and $1.0 \%$, respectively, $\mathrm{pH}$ decreased to 3.83 and acidity increased to $1.21 \%$ in $\mathrm{Y} 3$ as the concentration of whey increased in yoghurt. But, when whey concentration increased more than $20 \%$ then pH slightly increased in Y4 (3.88) and Y6 (4.11) while acidity decreased in Y4 $(1.19 \%)$ and Y6 $(1.01 \%)$, respectively (Table 2). During 21 days of storage the $\mathrm{pH}$ values of all yoghurt samples were decreased from 4.35 to 3.65 (Figure 1). It was observed that acidity values of all yoghurt samples were increased from $0.85 \%$ to $1.26 \%$ during storage. The acidity values of Y5 and Y6 were decreased could be due to a higher content of total solids (specially lactose) which minimize the viability of starter culture. Reduction in microbial activity by the higher content of concentrated whey was an exciting aspect which may contribute to extend the shelf life of the yoghurt. It was concluded that low level of acidity in yoghurt was due to the whey separation [23]. It was studied that whey powder with high lactose content used in yoghurt can lead to the fast production of lactic acid [27]. The increse in acidity and decrease in $\mathrm{pH}$ were due to the production of lactic acid from lactose by lactic acid bacteria (LAB) during storage [36]. The $\mathrm{pH}$ values of the yoghurt altered due to the fermentation of yoghurt by starter culture which convert lactose into lactic acid. It was observed that non-significant effect $(p>0.05)$ of fat (\%) among all yoghurt samples, as fat was standardized at $3.50 \%$ for each sample (Table 2). Fat content of all samples was decreased significantly during storage from $3.49 \%$ to $3.36 \%$ after 0 to 21 days respectively (Table 1 ). Previous study shows that lipolysis in yoghurt caused by many factors like lipase activity, fat globule vulnerability, physical, chemicals and thermal factors [29]. The protein, non-protein nitrogen, lactose and ash\% of yoghurt were increased by increasing the concentration of concentrated whey in yoghurt during manufacturing (Table 2). It was observed that difference between the protein content $(4.02-4.03 \%)$ of all yoghurt samples were non-significant from 0 to $7^{\text {th }}$ day of storage, then decreased to $3.99 \%$ on the $14^{\text {th }}$ day and remained non-significant up to the $21^{\text {st }}$ day of storage
(3.97\%). It was observed that all samples contain a minor but continuous increase of NPN; however, the average increase of NPN was from $0.22 \%$ to $0.31 \%$. The results of the research revealed that the variation in the present study might be due to the presence Lactobacillus bulgaricus and Streptococcus thermophilus, which were more proteolytic than other microbes. It was observed that lactose contents were significantly $(\mathrm{p}<0.05)$ decreased during storage due to the fermentation of lactose [36].

\subsection{Physical Analysis of Yoghurt}

It was observed that at $1^{\text {st }}$ day, Y2 had the low syneresis $5.51 \%$, followed by Y1 $5.79 \%$, while, Y6 had the high syneresis $17.15 \%$, then significantly $(\mathrm{p}<0.05)$ increased to $9.70 \%, 10.21 \%$ and $25.70 \%$, respectively after 21 days (Figure $1)$.

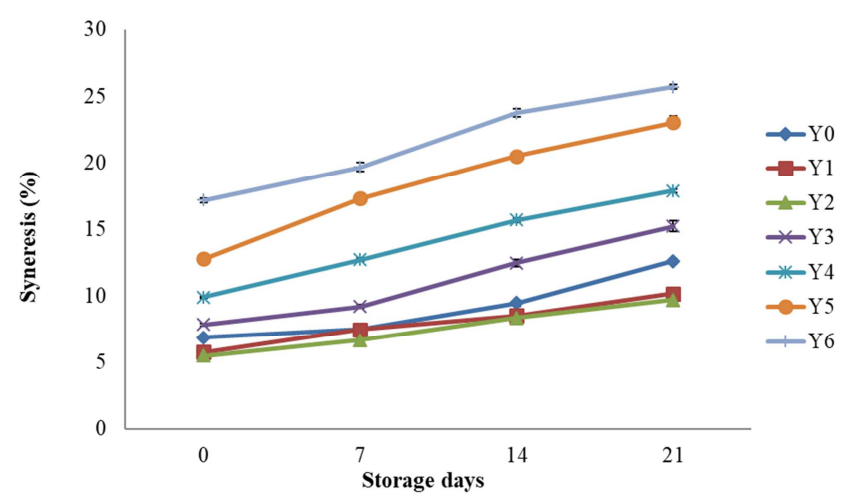

Figure 1. Syneresis of yoghurt samples during storage. YO= Control sample $Y 1=95 \%$ milk $+5 \% \mathrm{CW}, Y 2=90 \%$ milk $+10 \% \mathrm{CW}, \mathrm{Y3}=85 \%$ milk $+15 \%$ $C W, Y 4=80 \%$ milk $+20 \% \mathrm{CW}, \mathrm{Y5}=75 \%$ milk $+25 \% \mathrm{CW}, \mathrm{Y} 6=70 \%$ milk + $30 \% \mathrm{CW}$.

The results revealed Y6 had the low WHC 66.18\%, followed by Y5 $69.15 \%$, while Y2 had the high WHC $81.05 \%$ at $1^{\text {st }}$ day which significantly $(\mathrm{p}<0.05)$ decreased to $50.93,53.17$ and $63.23 \%$ respectively after 21 days (Figure 2). It was observed that $\mathrm{Y} 6$ had the low viscosity $2069 \mathrm{cp}$, followed by Y5 $2236 \mathrm{cp}$, while Y2 had the high viscosity 
$2907 \mathrm{cp}$ at $1^{\text {st }}$ day which significantly $(\mathrm{p}<0.05)$ decreased to $986 \mathrm{cp}, 1108 \mathrm{cp}$ and $1643 \mathrm{cp}$, respectively after 21 days (Figure 3). It was observed that the yoghurt samples Y6, Y5 and Y4 exhibited the high syneresis, low WHC and viscosity, while Y2 and Y1 showed low syneresis, high WHC and viscosity as compared to others yoghurt samples (Figure 2$3)$. Results variation in syneresis, viscosity and WHC of yoghurt samples might be due to high total solid contents especially lactose present in concentrated whey which inhibited the viability of starter culture. It was studied that yoghurt with $5 \% \mathrm{w} / \mathrm{w}$ lactose exhibited the high syneresis and low viscosity as compared to $0 \%, 1 \%$, and $3 \% \mathrm{w} / \mathrm{w}$ added lactose during storage period of $7^{\text {th }}$ day to $21^{\text {st }}$ day [9].

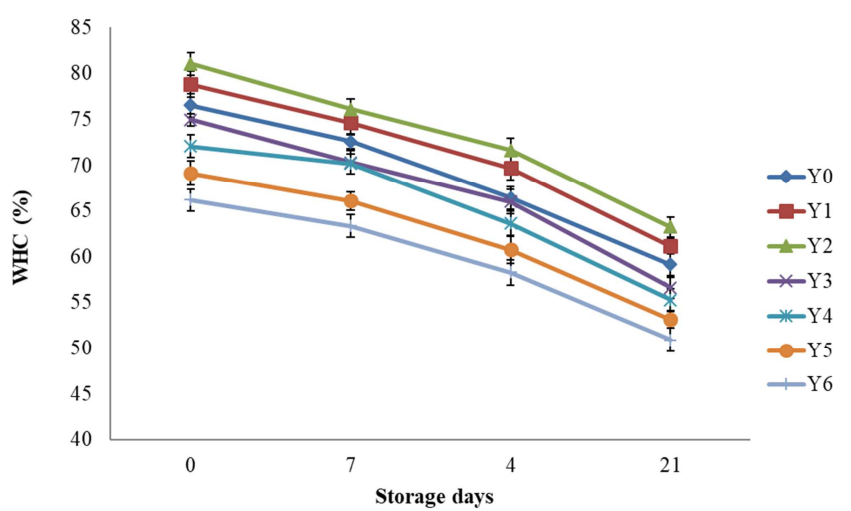

Figure 2. Water holding capacity of yoghurt samples during storage. $Y 0=$ Control sample $Y 1=95 \%$ milk $+5 \% \mathrm{CW}, \mathrm{Y} 2=90 \%$ milk $+10 \% \mathrm{CW}, \mathrm{Y3}=$ $85 \%$ milk $+15 \% \mathrm{CW}, \mathrm{Y} 4=80 \%$ milk $+20 \% \mathrm{CW}, \mathrm{Y5}=75 \%$ milk $+25 \% \mathrm{CW}$, $Y 6=70 \%$ milk $+30 \% \mathrm{CW}$.

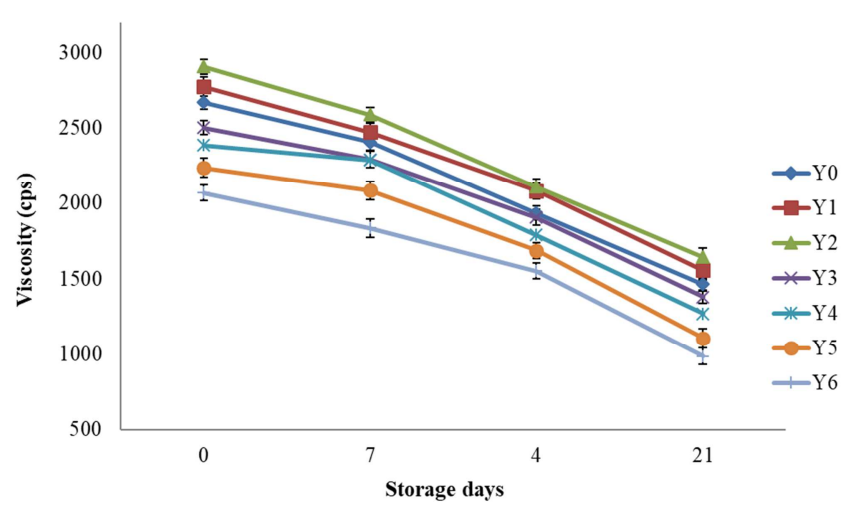

Figure 3. Viscosity of yoghurt samples during storage. $Y 0=$ Control sample $Y 1=95 \%$ milk $+5 \% C W, Y 2=90 \%$ milk $+10 \% C W, Y 3=85 \%$ milk $+15 \%$ $C W, Y 4=80 \%$ milk $+20 \% C W, Y 5=75 \%$ milk $+25 \% \mathrm{CW}, Y 6=70 \%$ milk + $30 \% \mathrm{CW}$.

It was observed that the quantity of whey syneresis increased and viscosity significantly $(\mathrm{p}<0.05)$ decreased as the degree of lactose hydrolysis increased [23]. It was observed that syneresis could be prevented by increasing total solids $(14 \%$ to $16 \%)$ by incorporating a high concentration of proteins and fat into yoghurt [5]. Sodini et al. concluded that WPC increased interactions among casein and whey protein which caused retention of water in the gel network of yoghurt [33]. It was studied that high concentration of whey proteins affected the yoghurt syneresis as yoghurt fortified with $0.75 \mathrm{~g}$ whey protein had $44 \%$ syneresis while yoghurt having $2.07 \mathrm{~g}$ whey proteins had $16 \%$ syneresis [28]. However, syneresis of yoghurt remained constant having similar whey protein contents but different total solid contents. Yoghurt prepared with $12 \%$ and $9.5 \%$ solids had syneresis of $11 \%$ and $10 \%$, respectively. It was observed that high concentration of acid production and increasing storage temperatures examined to increase the syneresis in yoghurt [30]. The interactions of whey-casein could be related to syneresis as the numbers of interactions increased, which ultimately increased the more connections in the network, due to which greater amounts of water was retained [20]. It was studied that when WPC added by replacing skim milk, then water-retention ability in the yoghurt increased and syneresis decreased [12]. It was studied that WHC was increased due to protein denaturation in yoghurt products [33]. It was studied that whey proteins denaturation increased the gelling properties with adequate heat treatment and increased the surface area which allowed increased water retention in the yoghurt matrix [2]. It was reported that Brookfield viscosity (10 to 30 Pas) with six yoghurts produced with six different WPC (340 to $800 \mathrm{~g} \mathrm{~kg}^{-1}$ protein) while concentrated whey increased the viscosity of yoghurt [16]. It was observed that addition of WPC as an ingredient in the mixture of yoghurt reduced the syneresis, increase firmness and viscosity [21]. Researchers also studied that yoghurt containing whey proteins denaturation from 25 to $75 \%$ showed more viscosity increased firmness, WHC and less syneresis [20]. Viscosity was affected by the solid contents and increased by increasing solids content in milk for the preparation of yoghurt. It was observed that the viscosity of yoghurt was increased by increasing its total solids. It was observed that the yoghurt prepared from whey powder fortification containing $4.2 \%$ protein by substituting SMP enhanced more density and its viscosity [15]. It was concluded that viscosity of buffalo milk yoghurt was significantly $(\mathrm{p}<0.05)$ decreased during storage [17].

\subsection{Sensory Evaluation of Yoghurt}

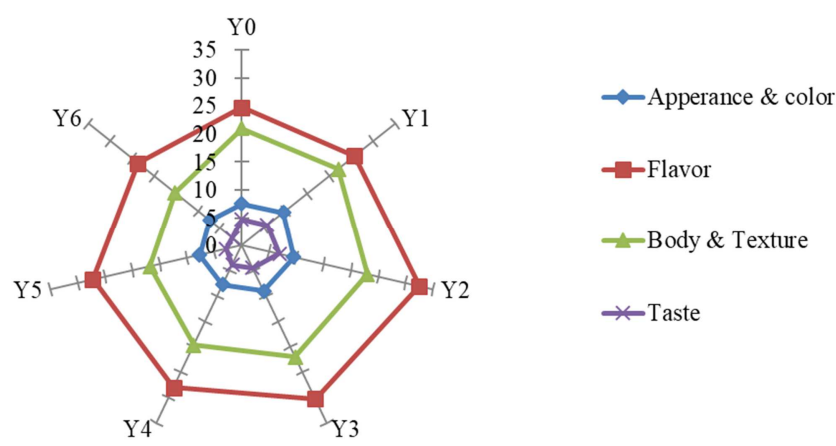

Figure 4. Mean values of sensory evaluations of yoghurt samples. Y0= Control sample $Y 1=95 \%$ milk $+5 \% \mathrm{CW}, \mathrm{Y} 2=90 \%$ milk $+10 \% \mathrm{CW}, \mathrm{Y3}=$ $85 \%$ milk $+15 \% \mathrm{CW}, Y 4=80 \%$ milk $+20 \% \mathrm{CW}, \mathrm{Y} 5=75 \%$ milk $+25 \% \mathrm{CW}$, $Y 6=70 \%$ milk $+30 \% \mathrm{CW}$.

The outcome of the sensory attribute (Figure 4) revealed that Y2 (10\% concentrated whey) got the best sensory scores as compared to other yoghurt samples followed by the $\mathrm{Y} 3$ 
(15\% concentrated whey), while the lowest scores were obtained by the Y6 and Y1. It was observed that Y5 and Y6 samples had bitter in taste and dark yellow in color. The dark yellow color of Y6 and Y7 could be due to high heating before and during yoghurt processing and high lactose content. Researcher also studied that whey powder increased yellowish color in yoghurt during its processing and the color intensity was proportional to the amount of added whey [15]; [35]. Whey powder is processed on high temperature and is likely to be affected regarding protein quality in terms of coagulation, precipitation and denaturation whereas concentrated whey has been processed at $60^{\circ} \mathrm{C}$ which is likely to result in better protein quality.

\section{Discussion}

The results indicated that the effect of concentrated whey on physicochemical and qualitative characteristics of yoghurt samples differed, depending on concentration and storage times. Overall acidity, viscosity, WHC, NPN, protein, lactose, ash and total solids of yoghurt significantly $(p<0.05)$ increased as the quantity of concentrated whey was increased in yoghurt formulation. Total solids, $\mathrm{pH}$, lactose, WHC and viscosity significantly $(\mathrm{p}<0.05)$ decreased during storage, while syneresis and acidity significantly $(p<0.05)$ increased during the storage period. Addition of concentrated whey at a certain concentration level can be useful for yoghurt production which affects its physicochemical and qualitative characteristics. Concentrated whey at $10 \%$ concentration level of fortification to produce set type yoghurt is appropriate. Increasing the concentrated whey component more than $10 \%$ resulted in the increase in a bitter taste, changed appearance $\&$ color, flavor and texture rendering it unacceptable to the consumer. Moreover, an increase in the acidity, NPN, lactose and syneresis and total solid contents have been observed as the concentration of concentrated whey was increased more than $10 \%$ in yoghurt formulation.

\section{Conclusion}

The findings of current research are useful for developing and improving the quality of functional products developed by food process industries. Addition of concentrated whey in the yoghurt is recommended for better quality of food products. In the low income country like Pakistan, the byproduct of cheese like whey can help to obtain valuable components from such economic resources and may use in food industries. Additional studies should be undertaken to determine the maximal shelf life of yoghurt supplemented with concentrated whey.

\section{Acknowledgements}

Authors thanks the IT Department, University of Veterinary and Animal Sciences (UVAS) Lahore, Higher Education Commission (HEC), Islamabad and Library
Department, Pakistan Council of Scientific Industrial Research Centre (PCSIR), Lahore for access to journals, books and valuable database.

\section{Conflict of Interest}

Authors are fully responsible all for this research and have not any conflict of interest.

\section{Compliance of with Ethical Standards}

Authors do not have any potential conflict of interest in this research. The human panel (UVAS panel) check the quality and sensory evaluation and fully prove the research. There are no any harmful chemicals used in this research.

\section{References}

[1] Ahmad S, Anjum FM, Huma N, Sameen A, Zahoor T. Composition and physico-chemical characteristics of buffalo milk with particular emphasis on lipids, proteins, minerals, enzymes and vitamins. J. Anim Plant Sci. 23 (1): 62-74 (2013).

[2] Akhtar M, Dickinson E. Emulsifying properties of whey protein-dextran conjugates at low $\mathrm{pH}$ and different salt concentrations. Colloids and Surfaces B. Biointerfaces. 31 (1): 125-132 (2003).

[3] Almeida KE, Tamime AY, Oliveira MN. Acidification rates of probiotic bacteria in minas frescal cheese whey. LWT Food Sci Technol. 41: 311-316 (2008).

[4] Alsaed AK, Ahmad R, Aldoomy H, El-Qader SA, Duaa S, Sakejha H, Mustafa L. Characterization, concentration and utilization of sweet and acid whey. Pak J Nutr. 12 (2): 172-177 (2013).

[5] Amatayakul T, Sherkat F, Shah NP. Syneresis in set yoghurt as affected by EPS starter cultures and levels of solids. Int J Dairy Technol. 59 (3): 216-221 (2006).

[6] Anema SG, Li Y. Effect of $\mathrm{pH}$ on the association of denatured whey proteins with casein micelles in heated reconstituted skim milk. J Agric Food Chem. 51 (6): 1640-1646 (2003).

[7] AOAC. Official Methods of Analysis of AOAC. Intl. 19 $9^{\text {th }}$ ed. Association of Official Analytical Chemist. Arlington, VA, USA (2012).

[8] Ayar A, Sert D, Kalyoncu H, Yazici F. Physical, chemical, nutritional and organoleptic characteristics of fruit added yogurts. J Food Technol. 4: 44-49 (2006).

[9] Chalas BJM. Influence of "added" lactose on probiotic properties of yoghurt culture bacteria and yoghurt characteristics. Master's thesis, Louisiana State University, Baton Rouge, LA, USA (2013).

[10] Cobos A, Horne DS, Muir DD. Rheological properties of acid milk gels. 1. Effects of composition, process and acidification conditions on products from recombined milks. J Food Sci. 50: 444-448 (1995).

[11] Damian C. Influence of dietary fiber addition on some properties of yoghurt. Ovidius Univ Ann Chem. 24 (1): 17-20 (2013). 
[12] Delikanli B, Ozcan T. Effects of various whey proteins on the physicochemical and textural properties of set type nonfat yoghurt. Int J Dairy Technol. 67: 495-503 (2014).

[13] El-Sheikh M, Farrag A, Zaghloul A. Ricotta cheese from whey protein concentrate. J Am Sci. 6 (8): 321-325 (2010).

[14] Gillani Z, Huma N, Sameen A, Shahid M. Influence of storage temperatures on the quality of concentrated whey. Pak J Agri Sci. 52: 527-532 (2015).

[15] Gonzalez-Martinez C, Becerra M, Chafer M, Albors A, Carot JM, Chiralt A. Influence of substituting milk for whey powder on yoghurt quality. Trends Food Sci Technol. 13: 334-340 (2002).

[16] Guzman-Gonzalez M, Morais F, Ramos M, Amigo L. Influence of skimmed milk concentrates replacement by dry dairy products in a low fat set-type yoghurt model system. J Sci Food Agri. 80: 433-438 (1999).

[17] Hanif MS, Zahoor T, Iqbal Z, Ihsan-ul-haq, Arif AM. Effect of storage on the rheological and sensory characteristics of cow and buffalo milk yoghurt. Pak J Food Sci. 22 (2): 61-70 (2012).

[18] IDF. Standard. Milk: Determination of nitrogen content (Kjeldahal method). IDF Standard 20-A. Int. Dairy Fed. Brussels, Belgium (2001).

[19] Kelly PM, O'Kennedy BT. The effect of casein/whey protein ratio and minerals on the rheology of fresh cheese gels using a model system. Int Dairy J. 11: 525-532 (2001).

[20] Lee WJ, Lucey JA. Rheological properties, whey separation and microstructure in set-style yoghurt: effects of heating temperature and incubation temperature. J Texture Stud. 34: 515-536 (2007).

[21] Lucey JA, Tamehana M, Singh H, Munro PA. A comparison of the formation, rheological properties and microstructure of acid skim milk gels made with a bacterial culture or glucono$\delta$-lactone. Food Res Int. 31: 147-155 (1998).

[22] Marshall RT. Standard methods for the examination of dairy products. $16^{\text {th }}$ ed. American Publication Health Association, Washington, DC, USA (1993).

[23] Nagaraj M, Sharanagouda B, Manjunath H, Manafi M. Standardization of different levels of lactose hydrolysis in the preparation of lactose hydrolyzed yoghurt. Iran J Vet Res. 10: 132-136 (2009).

[24] Narayana NMNK, Gupta VK. Quality of cow milk plain set yoghurt as affected by ultrafiltration process. Tropical Agric Res Ext. 16 (3): 74-80 (2013).
[25] Ong L, Henriksson A, Shah NP. Chemical analysis and sensory evaluation of cheddar cheese produced with Lactobacillus acidophilus, Lactobacillus casei, Lactobacillus paracasei, or bifidobacterium sp. Int J Dairy Sci. 17: 67-78 (2007).

[26] Patocka G, Cervenkova R, Narine S, Jelen P. Rheological behavior of dairy products as affected by soluble whey protein isolate. Int Dairy J. 16: 399-405 (2006).

[27] Penna A, Baruffaldi R, Oliveira N. Optimization of yoghurt production using demineralized whey. J Food Sci. 62: 846-850 (1997).

[28] Puvanenthiran A, Williams RPW, Augustin MA. Structure and visco-elastic properties of set yoghurt with altered casein to whey protein ratios. Int Dairy J. 12: 383-391 (2002).

[29] Ray PR, Chatterjee K, Chakraborty C, Ghatak PK. Lipolysis of milk: a review. Int J Agri Sci Vet Med. 1: 58-74 (2013).

[30] Richmond ML, Harte BR, Gray JI, Stine CM. Physical damage of yoghurt. The role of secondary packaging on the stability of yoghurt. J Food Prot. 48: 482-486 (1985).

[31] Sahan N, Yasar K, Hayaloglu AA. Physical, chemical and flavor quality of non-fat yoghurt as affected by a $\beta$-glucan hydrocolloidal composite during storage. Food Hydrocoll. 22: 1291-1297 (2008).

[32] Sandoval-Castilla O, Calleros CL, Aguirre EM, Vernon CEJ. Microstructure and texture of yoghurt as influenced by fat replacers. Int Dairy J. 14: 151-159 (2004).

[33] Sodini I, Montella J, Tong PS. Physical properties of yoghurt fortified with various commercial whey proteins concentrates. J Sci Food Agric. 85: 853-859 (2005).

[34] Steel RGD, Torrie JH, Dickey DA. Principles and Procedures of Statistics. A Biometrical Approach. $3^{\text {rd }}$ ed. McGraw Hill Book, Co Inc, NY, USA. pp. 144-147 (1997).

[35] Supavititpatana P, Wirjantoro TI, Raviyan P. Effect of sodium caseinate and whey protein isolate fortification on the physical properties and microstructure of corn milk yoghurt. J Natural Sci Biol Med. 8: 247 (2009).

[36] Tamime AY, Robinson RK. Tamime and Robinson's Yoghurt Science and Technology. $3^{\text {rd }}$ ed. Wood head Publishing Ltd. Cambridge, UK. p. 468 (2007).

[37] Tamime AY, Law BA. Mechanization and Automation in Dairy Technology. $3^{\text {rd }}$ ed. John Wiley \& Sons, UK. pp. 152203 (2001). 